\title{
Gaining access to everyday life information seeking
}

\author{
Robert F. Carey, Lynne E.F. McKechnie*, Pamela J. McKenzie \\ Graduate Program of Library and Information Science, Faculty of Information and Media Studies, Middlesex \\ College, The University of Western Ontario, London, Ontario N6A 5B7, Canada. \\ E-mail address: mckechnie@uwo.ca (L.E.F. McKechnie).
}

\begin{abstract}
The discursive viewpoint adopted by many researchers who study everyday life information seeking allows for a shift in focus away from the individual as a unit of analysis toward a more general understanding of the broader cultural conditions within which individuals operate. However, the data employed by such researchers often consist of the testimony or observed actions of individuals. This paradox provides a point from which to reflect on the process of gaining access or entry to everyday life information seekers as research participants. This article presents the authors' reflections on their experiences of conducting separate library and information science studies of three diverse populations: pregnant women, members of a self-help support group, and preschool children. The article's premise is that theory and research practice are intertwined and that attending to issues of gaining access is essential for the development of both. Access is an emergent process dependent on the characteristics of the researcher, the participants, and the research context. (C) 2001 Elsevier Science Inc. All rights reserved.
\end{abstract}

\section{Introduction}

During the last 20 years, library and information science (LIS) researchers have developed a growing body of scholarship on everyday life information seeking (ELIS). Savolainen (1995) defines ELIS as "the acquisition of various informational (both cognitive and expressive) elements which people employ to orient themselves in daily life or to solve problems not directly associated with the performance of occupational tasks" (pp. 266-267).

Much attention has been devoted to the application of social theory to ELIS (e.g., Savolainen, 1995) and the development of new theoretical frameworks (e.g., Chatman,

\footnotetext{
* Corresponding author.
} 
1999). In particular, researchers in the field of information studies have begun to explore the discursive viewpoint, which is "a theory about the production of language. This viewpoint abandons the individual as the unit of analysis and shifts the focus to a more general level: to the variability of knowledge formations" (Vakkari, 1997, p. 455). Included in the general level to which Vakkari refers are the discourses that legitimate the ways people come to understand the world around them.

This viewpoint invites close investigation of groups and settings that have been traditionally underrepresented in LIS research. But careful attention to people's everyday worlds remains a crucial source of data for researchers whose inquiry explores the link between the structural and the personal or, in Mills' (1959) phrase, public issues and private troubles. The increasing prevalence of such theoretically rich perspectives in LIS both invigorates and creates problems for a qualitative approach to information studies; these new perspectives demand critical thought about the relationship between the observer and the observed, and about the ways in which LIS researchers co-construct this relationship. Such reflection can contribute to the development of both theory and sound research practices.

Although LIS researchers have used field methods and naturalistic settings to explore ELIS among such diverse populations as prisoners (Chatman, 1999), senior citizens (Pettigrew, 1999; Williamson, 1997), adolescents (Green \& Davenport, 1999; Julien, 1999), homeless people (Hersberger, 1998), and battered women (Harris \& Dewdney, 1994), they have devoted little attention to sharing the details of their research methods. Research practices such as developing interview schedules, identifying appropriate populations to study, and the reporting process rarely form part of research publications and are often not adequately described in research method texts. For example, although Chatman (1984) pointed out that access - gaining entry to participants over a sustained period - is fundamental to the research process in naturalistic settings, Gorman and Clayton (1997) observed that in LIS the issue of gaining access is "largely ignored in the few writings on qualitative methodologies in the information area, but it is also not addressed in most of the research papers that report on qualitative investigations in this field" (p. 88).

A perusal of LIS research method texts that consider qualitative approaches - including those by Busha and Harter (1980), Glazier and Powell (1992), Losee and Worley (1993), Mellon (1990), and Powell (1997) - confirms this statement. In fact, with the exception of a brief section in Gorman and Clayton (1997), which describes strategies for gaining but not maintaining access, to our knowledge, Chatman's (1984) piece is the only article in the LIS literature that treats access as a subject of reflection and analysis. This gap is also evident in other social science literature. Harrington (1998), for example, observed that stories about the techniques researchers use to gain entry tend not to be heavily emphasized in the sociological "classics." As a result, "there is no cumulative knowledge base from which researchers can draw when trying to solve the problem of access. Each must discover the problem anew, and reinvent the wheel in solving it" (Harrington, 1998, not paginated).

Accordingly, this article seeks to fill the gap in the LIS methodology literature by sharing insights derived from the authors' experiences conducting separate ELIS studies of three populations: pregnant women, members of a self-help support group, and preschool children. This article reflects on the processes of gaining and maintaining access to the respective 
participants and draws together common themes in order to make explicit the tacit practices that guide qualitative ELIS researchers.

One theme common to our experiences is that gaining access required more than simply following prescriptions outlined in textbooks about research methods, many of which propose that access is a function of personal connections (Lofland \& Lofland, 1984), persistence (Whyte, 1943), luck (Berg, 1989), being prepared with persuasive accounts of research intent (Palys, 1997), and courtesy (Denzin \& Lincoln, 1994). Although these are necessary elements in gaining access, the means by which they are usefully employed vary among researchers. When we compared our accounts of fieldwork, for example, it became clear that our use of certain techniques for gaining access was predicated by the extent to which we shared certain "insider" characteristics with our participants:

"Insiders' experiences are shaped by the fact that they share a common cultural, social, religious, or other perspective. It is these common experiences that provide expected norms of behavior and ways to approach the world. They also define those things that are important to pay attention to and those things that are not" (Chatman, 1996, p. 194).

Because we started out with varying degrees of insider knowledge, we experienced distinctly different relationships with our participants, each of which involved unique expectations, obligations, and insights. An important commonality is that our process of gaining and maintaining access involved the same kind of iterative attention that characterizes qualitative analysis. By constantly attending to - and thinking about — the ways the participants regarded us, we allowed them to lead us in the act of discovery. The hope is that sharing our stories from the field will provide a starting point for disseminating, extending, and critiquing the tacit assumptions held by LIS field researchers, both by building on Chatman's (1984) work and by encouraging further discussion about access.

\section{Researcher as insider: Gaining access to pregnant women}

Lincoln and Guba (1985) noted that the researcher is the primary data collection instrument in a naturalistic study. In the study that follows, the author addressed the construction of authoritative knowledge and the information-seeking practices of women who were pregnant with twins, and the author's own experience as a mother of twins proved invaluable both in gaining initial access to participants and in gaining and maintaining their trust over the course of the study period.

The rarity of twin pregnancy - about one in every hundred (Pernoll \& Benson, 1994) and the relatively short period of pregnancy meant that the pool of potential participants at any given time was very small. Based on other studies of this population (e.g., Van der Zalm, 1995), it was expected that participants could be recruited by contacting health care providers and a local twin parenting organization, placing newspaper ads, distributing publicity flyers, and acquiring referrals through snowball sampling. As a former member of the twin parenting organization, I had volunteered on committees whose membership included maternity and infant health care providers. The experience I gained and the 
connections I made doing that work granted me insider status with gatekeepers in two potential recruiting sites: the local health unit's prenatal "fairs" and meetings of the twin parenting organization.

My committee participation facilitated gaining access to prenatal fairs when a familiar nurse expedited the approval of my proposal. This assisted me in making informal contact with fair exhibitors, who included both familiar and unfamiliar public health staff, midwives, private prenatal educators, nurses, and business people. I began the regular practice of visiting every relevant display booth with flyers in hand and describing my study to anyone who would listen. Exhibitors took my brochures to give to their pregnant acquaintances or to display in their workplaces. In addition, they occasionally referred potential participants to me during the fairs, as shown in the following field notes:

I initially met Amina at the prenatal health fair. The county health unit has a display on fetal development with plastic models of fetuses in utero. One of the models shows twins. Very few minutes after I had been introduced to the public health nurses working at the prenatal health fair, Amina was looking at the plastic model and told the health nurse at this display that she was pregnant with twins. The health nurse called me over to meet her.

My insider status was most clearly acknowledged in the twin parenting association. The association president, an acquaintance from my previous membership, immediately gave me permission to attend meetings during my data collection period. My field notes show how my social connections within the organization facilitated the initial contact with a participant:

I first met Gayle at the general meeting 1 week prior to our initial interview. I told her about the study but we didn't talk much. Another mother of twins who was a mutual acquaintance introduced me and told Gayle that I was the mother whose child had asked "Mommy, are we double trouble?" after a comment from a passer-by.

This introduction legitimated me to Gayle as a trustworthy insider: a mother of twins who had experienced, and therefore understood, public stereotypes.

Snowball sampling proved not to be useful because participants did not know other women currently pregnant with twins. However, both my own and my participants' social network contacts served as very effective gatekeepers. Five of my acquaintances told me about pregnant women they knew. Three of these women eventually participated in my study. I began to carry a supply of flyers or business cards with me wherever I went and distributed them at any opportune occasion. One referral came from passing my business card to a friend in the parking lot of my children's school.

Members of the participants' own social networks, most of whom I never met, acted as gatekeepers by passing my ads on to pregnant women. Of the six women who contacted me after reading my print ads, five had been shown the ad by an acquaintance, friend, or family member. One woman had in fact received copies of the ad from three different people. Many women seemed to need time to consider participating, and having a friend or family member endorse the study by passing on the ad often served as the catalyst. Both my recruitment flyers and newspaper ads highlighted my insider status by describing me as a "university researcher and mother of twins." Rachel, desperate for contact with other mothers of twins, had been unsuccessful in contacting the parenting organization. After seeing my ad for the 
second time, her husband suggested that participating in my study might provide her with the peer contact she sought.

\subsection{Building trust with women and their families}

Once I had made contact with a potential participant, an initial preparticipation conversation provided an excellent opportunity to establish the trust required for the women to let me into their homes and lives. All of the women I spoke to eventually agreed to participate, although a few initially expressed misgivings, based on their understanding of what the research would entail. Holly's partner wondered, "Is she coming to steal a baby for 15 years? [laughs] And see if they're alike?" One woman asked if she would need to leave a urine sample. Initial conversations with some women were extremely short and businesslike. Others, however, began to talk immediately about their experiences; I quickly took field notes while these women shared important and often very intimate details.

One component of establishing a trusting relationship involved gaining access to women within the context of their family and work lives. This process involved both logistical arrangements, such as scheduling interviews around women's work, childcare, or doctors' appointments, and gaining the trust and cooperation of other members of the women's households, including partners, children, tenants, and pets. Several partners met me as I arrived in their homes. Some stayed in the room for all or part of the interview, and a few contributed to the conversation. I accommodated participants' children as much as possible. I was aware that the study disrupted children's routines and that my interactions with children would affect my trusting relationship with their mothers. I stopped the tape recorder for a diaper change or a snack, included children in conversations, cared for them when their mothers left the room, and let them explore my equipment and supplies. Lynn's consent form is decorated with pictures her son drew with my pen, and I noted that he "made me pretend tea."

Once we had established an initial rapport, my participants were extremely forthcoming. As others researching this population have found (Frank, 1997; Van der Zalm, 1995), my status as someone who had "been through it" helped in providing a comfortable and trusting environment for respondents to disclose their feelings and experiences. Oakley (1981) suggested that reciprocal exchange may be more effective than the traditional research interview model (with the informant as "giver" and the researcher as "receiver") when interviewing women about such issues as pregnancy and childbirth. I offered all participants the opportunity to question me about the study and my experiences. In answering their questions, I was able to offer emotional support, experiential knowledge, and referrals to my own mothering resource network. The reciprocity of disclosure fostered the ongoing trusting relationship, and women's questions about my experience often led to unanticipated and datarich discussions of issues we had not yet broached.

Women demonstrated their trust in several ways. Rachel used me as an authority in trying to convince her mother that she would need more help once her babies were born: "Mom, this is reality. This is someone who had twins. They had no sleep [laughs; emphasis in original]." Several women trusted me sufficiently to disclose private details about their lives, which they indicated they did not want widely shared. One participant waited until the tape 
recorder was turned off to describe changes in her sexuality since becoming pregnant, while another said, "Thank God this is confidential," before sharing her concerns about mental illness in her family. A third woman disclosed that she had considered terminating this pregnancy. A trusting relationship is also evident in the extraordinary respect and responsibility women demonstrated toward the study. Several called to rearrange appointments when schedules changed. At the end of my interviewing week with Patty, I observed in my field notes that she "asked if I would be talking to her again and seemed to be surprised when I said that was it. She offered twice that I could call her back if I had any more questions."

My role as a mother of twins conferred on me a specialized insider status, facilitating access to many appropriate gatekeepers and allowing me to offer a particular kind of reciprocity to pregnant women. Reay (1995) found, however, that insider status was not always sufficient in and of itself for gaining access. However negotiated, insider status does not guarantee a smooth and static relationship with participants. That relationship continued to evolve over the course of our interactions. Sensitivity to the limits of insider status was crucial. On the one hand, acknowledging each woman as an expert about her own life was necessary for gathering rich data. On the other, maintaining the role of experienced insider was the key to building trust. Negotiating a balance between these was an ongoing task.

\section{Researcher as outsider: Gaining access to a support group}

Gaining access to self-help support groups poses special difficulties, some of which are due to the egalitarian nature of the self-help ethos (Gottlieb, 1982; Kingree \& Ruback, 1994). Since many self-help groups attempt to distribute authority equitably among their members, the usual tactic of finding a gatekeeper to sponsor the researcher may not be wholly effective; the gatekeeper may be unable or unwilling to convince other members to accept the field researcher. Even with a gatekeeper's sponsorship, the researcher may find it difficult to sustain access or to gain cooperation from other members (Kennedy, Humphreys, \& Borkman, 1994).

This study involves participant observation of a self-help support group for people with a chronic auto-immune illness. This research was guided by the following question: How do members of the group convey and interpret varieties of knowledge through storytelling, illness narratives, and other types of discourse that reflect personal experience? Previous research into the health information needs of various populations has frequently exhibited an emphasis on institutional perspectives. The overt purpose of much inquiry in this vein has been to identify patients' information needs and to recommend ways these needs can be better met by information systems for health care professionals. Such studies have implicitly tended to support positions that preserve the power and privilege of the biomedical establishment. A preponderance of work, for example, has focused on encounters between physicians and patients in the belief that improving communication practices in these situations will minimize noncompliance with medical directives. This type of approach neglects ways in which the everyday reality of illness is understood and shared by the chronically ill and, moreover, ignores the political nature of health information exchange. 
The observational and interview data reported in this study were gathered between August 1999 and May 2001. The location for most of the research was a large urban center (population 316,000) in Ontario where I acted as a participant-observer at 14 support group meetings held in a local community center. I also conducted interviews with 25 group members at various sites: their homes, doughnut shops, a hospital cafeteria, and an office at the university.

My entry into the group began when the support group's leader agreed to sponsor me to the group after I presented her with an account of my research intentions. A more daunting challenge was convincing the 15 to 20 members of the group to participate in interviews and to accept my presence at meetings. As a researcher who does not share the credentials of membership - in this case, a chronic illness - I was concerned that many group members would object to my presence. Ultimately, however, almost all group members proved congenial to the research. Importance of the group members' understanding of the research act itself and its implications for gaining and maintaining access, a theme that has been addressed elsewhere (e.g., Dunlap \& Johnson, 1999; Fine, 1993; Ostrander, 1993) but is often not heavily emphasized in textbooks dealing with field methods (e.g., Erlandson, Harris, Skipper, \& Allen, 1993; Palys, 1997).

Before attending group meetings, I had been concerned about observer effect. Consequently, I wished to establish a role in the field that would minimize my presence as a researcher. During my initial conversations with the support group's leader, she mentioned that the group needed a librarian - someone to set up the library display prior to each meeting, maintain a sign-out sheet, and maintain the catalog. I assumed this role for the duration of the study. It was extremely useful insofar as it gave me ready access to the group's information resources and circulation records and encouraged interaction with group members. In the field, I tended to act as a participant immediately before and after meetings, when members were most likely to use the group's library resources. During the meetings themselves - which took the form of "rap sessions" or speeches from invited guests - I acted mainly as an observer.

As my engagement with the group continued, however, it became clear that my role as a researcher actually tended to invite participation from members. One reason may have to do with the fact that the chronic illness shared by the people in this group is not well known and not easily diagnosed. Moreover, people who have the illness frequently exhibit no obvious symptoms. Thus, group members tend to feel overlooked by the medical establishment. In this passage from an interview, Betty expressed the sense of marginalization she experiences as a result of the illness:

I really have no one else who understands or who is as knowledgeable as some of the people in the group ... it frustrates me sometimes when I say I'm in a lot of pain and he [Betty's husband] just kind of turns his head the other way.

For many group members, being interviewed by a researcher seemed to confer a sense of legitimation that validated their experience of illness. During our interview, Betty asked for an extra letter of information, saying she wanted one for herself and one for her husband. She explained this would help to impress him with the seriousness of her condition. Betty's 
interpretation of the research as evidence attesting to the reality of her suffering was a powerful motivation in her decision to participate.

In other cases, participants were particularly interested to learn what kind of researcher I was - specifically, whether I was a medical student, a medical researcher, or someone affiliated with a school of medicine. During the interviews, it emerged that this interest was sometimes connected to their previous experience with physicians and medical students, for whom some participants had developed either antipathy or bemusement. One participant, Jim, said the following:

You get the [medical] students who come in and, I don't know ... It's just stupid questions. Like, "How do you know you're sick?" Like, I understand from their point. But I don't have patience for that. Like, okay, ... let's get the real doctor in here.

The fact that group members valued the presence of a researcher as a way of legitimating their experience of illness was probably more decisive in maintaining access to the group than my participatory role as a librarian. Although I do not want to suggest that a field investigator should emphasize his or her status as a researcher in every setting, I want to emphasize that the meanings participants assigned to the research facilitated access in ways not anticipated prior to commencing the research. (This position does not obviate conventional measures taken to ensure rigor in qualitative research. Through prolonged engagement in the field, triangulation, and member checking, I assessed possible trustworthiness threats due to reactivity).

Another theme in gaining access to participants is the nature of rapport, always problematic when the researcher has no personal experience of the group's shared problem. Harrington (1998) stated, 'sympathy and approval are not things to be 'exchanged,' and are usually not well-received when presented in such a strategic light." This is particularly true of self-help support groups, whose ideologies frequently emphasize the singularity of their members (Rappaport, 1994). For example, group members frequently expressed suspicion of outsiders who were quick to offer support. Often such gestures were characterized as shallow, insensitive, or uninformed. One participant, Lynne, said the following:

We get to the point where we get really tired of hearing that line, "Oh, you look wonderful," because it's on the inside, it's what's going on on the inside. And I've even come back with that, "Yeah, I might look good on the outside, but you don't what the hell's going on, on the inside."

Because I respected group members' own distinctions between insiders (those who have the illness) and outsiders (those who do not), I never explicitly attempted to mitigate my status as an outsider. During interviews and informal conversations, I found that empathy and rapport could be cultivated around other kinds of shared experiences. Usually, these insights emerged through casual, undirected small talk. During one interview, for example, Alice and I commiserated about having to rely on public transportation to get around the city. Later, she explained why she sometimes didn't go for tests her doctor had arranged:

Sometimes, if I don't feel like going, I'm not going to travel on the bus to go for a test. They [doctors] don't realize this because they just get in a car and go, but you being on the bus yourself know how I feel [emphasis added]. 
Similarly, when I was loading a tape recorder prior to an interview with Christine, we exchanged stories about our experiences as graduate students. Later, she spoke about ways in which the group had provided emotional support during difficult periods:

When I graduated from the Master's program, they were just ecstatic, as ecstatic as I was. Because it was a horrendous thing [laughs]. You know what it's like to do that anyway, but to have a chronic illness on top of that, it was, yeah, really positive feedback [emphasis added].

Linguistic markers, such as those italicized in the previous example, are probably the most subtle ways that participants signaled acceptance. More obvious signs included a willingness to ask for favors. Originally, I had thought that my role as the group's librarian would allow me to offer something to the group in exchange for allowing me access. But this role actually afforded me little opportunity to "give back" to the group, since the volunteers in charge often had more urgent concerns than the library. Instead, they asked for reciprocity in other ways. During my 2 years with the group, I participated in fundraising efforts, board meetings, errands, and computer troubleshooting. These field experiences lend credence to Chatman's (1984) observation about the fluid nature of roles in the field; far from being fixed at the outset, roles are a shared project whose nature undergoes constant revision as the researcher and participants continuously redefine each other.

\section{Researcher as insider and outsider: Gaining access to children}

The responsibility parents and other adults hold for children and the developmental inability of children (especially very young children) to understand research imply that gaining access to child participants is shared with their adult caretakers (American Psychological Association, 1980; Ferguson, 1978). This became evident when I observed and recorded the naturally occurring behavior and talk of 30 preschool girls during a visit to their local public libraries with their mothers (McKechnie, 1996, 2000).

Identifying families was not a problem. Impersonal methods, such as flyers and advertisements in local newspapers, and more personal methods, such as referrals from library staff, worked equally well. As the children were too young to find and read promotional materials, my advertising was directed at adults. I described myself as a children's librarian, a mother, and a doctoral student. I believe this contributed to the mothers' willingness to have their daughters participate. From their perspective, my role as a researcher and a doctoral student identified me as an expert, and our shared contexts as library users and parents, situated me as an insider. But this was not true for the children. Fine and Sandstrom (1988) and Graue and Walsh (1998) noted that inherent differences in power between children and adults preclude an insider relationship between researcher and children. Acting mostly in the role of researcher as insider, my central task with the mothers was to enhance and maintain access, which was initially given quite readily. Acting mostly in the role of researcher as outsider, my central task with the children was to find a way to gain their trust so that they would allow me entry into their small worlds. 


\subsection{Working with the mothers}

Mothers often spontaneously explained why they had been attracted to the study. Several, like Lisa's, spoke of a lifelong love for reading and libraries. Over half the mothers, including Emily's mother (teaching), Antje's mother (social work), Madeline's mother (librarianship), and Hannah's mother (writing for children), had occupations similar to mine. Although I usually did not know this until well into data collection, these shared experiences also allowed the mothers to view me as an insider.

However, as can be seen in this excerpt from my interview field notes with Alexis' mother, initial willingness cannot always be construed as complete commitment to or comfort with the research:

I had encountered M [mother] and Alexis at the Children's Library while I was there doing another data collection. She had approached me to ask if I was the one she had talked to on the phone about participating in the study. I used this opportunity to ask $\mathrm{M}$ if being able to observe another data collection had been useful to her in any way. She told me that it had helped her understand what was involved and made her feel a bit less anxious about having her daughter in the study. She quickly noted that she had not really been worried but that she always wondered a bit about new experiences.

Further, although most follow-up interviews (27, or 90\%) took place in the children's homes, fewer mothers $(21$, or $70 \%$ ) invited me to their houses for the first information-sharing and informed-consent interview. I learned that paying attention to building and maintaining access is essential throughout, and not just at the beginning of the research process.

Although I used many of the access strategies described in the research methods literature, the mothers initiated what turned out to be the most important means for maintaining access: tea and adult conversation. After having completed the research interviews, seated at kitchen tables with the mothers while the children played nearby, I drank countless cups of tea while talking about parenting, children's literature, and kindergarten. Many of the mothers told me they had few opportunities to talk with another who, for the moment at least, was so interested in their child. For them, reciprocity came from the time we spent together as insiders, exchanging thoughts about a shared world.

\subsubsection{Working with the children}

Fine and Glassner (1979), Corsaro (1981), and Mandell (1988) stated that adult permission is never enough; children themselves act as gatekeepers of their involvement in a study. This became apparent in my work when two girls declined participation. Neither had been present for the first part of the interview when the study was explained to their mothers. One was at story hour, the other playing outside. What differentiated their experience from those who agreed to take part was that they did not have the opportunity to watch me interact with their mothers. It seemed the children had at least partially based their decision about whether I could be trusted on clues provided by the nature of their mothers' interactions with me, such as smiles, friendly tones of voice, and cooperative behavior. 
The children also monitored my actions. As can be seen from the following excerpt from my field notes, some needed time to establish trust:

Rebecca was very shy. She held on to her mother, covered her eyes and would not look at me for about the first 5 minutes. To break the ice, I asked about her shirt, about school and if she went to the library a lot. She gradually warmed up, uncovering her eyes, letting go of $\mathrm{M}$ and finally, actively exploring the equipment and talking.

It was also important to allow the children to explore the equipment, as shown from the following excerpt from my field notes:

Danielle was extraordinarily curious about all the study equipment. She completely dismantled and reassembled the tape recorder (batteries, microphone, earphones, cassette). She made me teach her how to use it and then operated the equipment independently and correctly. She asked me to explain the purpose of everything in my basket. When I showed her my field note package on the clipboard she wrote some of her own field notes on the first page. She asked me why I had two pens and two cardboard slips for the recorder. I explained that it was really important to have two of everything in case I lost one or one didn't work. Then she asked why I didn't have two recorders. I explained that they were very expensive.

Many of the girls also enjoyed listening to bits of others' previous library visits and asked to listen to themselves after their own sessions. All were encouraged to try on the shirt that housed the recorder and to select the shirt color - red or blue - that they would wear while at the library. This strategy helped to give them a sense of control and affirmed them as equal partners in the project. It soon became clear to me that gaining entry with the children did not just entail building rapport with them and their mothers. Children, with little experience or knowledge of research, need to make sense of, or orient themselves to, the concept. Researchers should provide age-appropriate opportunities for them to do this. In the case of the preschoolers in my study, this was achieved by allowing them to physically manipulate and play with the equipment and supplies.

In some cases, mothers acted as partners in gaining access, helping their daughters to understand the study, as shown in the following example from my field notes:

M said she had explained the study to Marissa and that they had talked about it several times. I explained it to Marissa again. She repeatedly told me that she knew about specific things in the process, reaffirming that she recalled her discussions with her mother. She readily agreed to take part.

Although appreciative of the mothers' assistance, to protect the children's rights I looked for evidence of coercion. Graue and Walsh (1998), Stanley and Sieber (1992), and Thompson (1992) noted that one cannot assume that parents are only motivated by the best interests of their children. Twice during library visits, noticing some distress on the part of the children, I stopped data collection. Both mothers assured me their daughters would be fine in a few minutes. Both times I was worried the mothers' desire to have their children in the study might be causing them to underestimate the girls' discomfort. Fortunately, the mothers were right and both children quickly resumed playing, looking at books, and smiling. 
Although none of the children could read or write at the time of my study, all of them "signed" the informed consent form. They also provided many other clues, mostly through their actions, that indicated they had allowed me into their worlds. They took me to see their toys, their bedrooms, and in some cases, their entire houses. They asked me to read stories to them and "read" to me. I was invited into a playhouse constructed of blankets and chairs, a "library" where I was given the role of a child at story time while Catherine played the librarian. For 1 week after the library visit, the mothers kept diaries in which they recorded any incidents related to the trip to the library or the use of library materials. They reported that their children told friends and relatives about the study, asked if I might be at the library now, and wondered when they would see me again. Sadako's mother noted that "just before we left for the library, Sadako was explaining the 'study' to our neighbor. She was really excited about the 'tape recorder'." Ruthie's mother wrote that her daughter was continually asking "When are we coming back? When are we doing it again?" After my final interview with Emily and her mother, I made the following field note:

As I was leaving, Emily ran up with a drawing she had made with M's marker. It was a picture of me. She had left off the arms. She quickly added them. As I drove off Emily waved and blew kisses at me from her dining room window.

When I arrived at Hannah's house to complete my final data collection session for the study, a library visit follow-up interview, she was waiting for me outside the front door. My field notes indicate that "Hannah opened the door and led me into the house." Although I never was successful at gaining entry as a peer or an insider, I was able to build rapport with the children as a trusted adult. Again and again, they took me by the hand and led me into their houses and their worlds.

\section{Conclusion}

Although these individual accounts are interesting in and of themselves, together they provide an opportunity to consider the problems of gaining access more generally. The shift in perspective afforded by the discursive viewpoint - from the individual as the unit of analysis to that of the cultural production of knowledge - did not preclude the close study of individuals in the contexts of their everyday lives. This shift provides an opportunity for LIS researchers to reflect on the research process itself: what this process attempts to discover about people and about the ways people are engaged in and by the world around them.

The discursive viewpoint is particularly concerned with the social contexts that shape the constitution and interpretation of knowledge (Talja, 1997). The purpose of inquiry that reflects these assumptions is to identify the means by which knowledge is generated and shared within a social field. Accordingly, this position leads away from the "user-psychological and individual-centered approaches" characteristic of the cognitive viewpoint (Talja, 1997, p. 68). Sensitivity to the means by which language reflects the interplay of personal experience and public issues allows researchers to understand how they are situated in relation to the 
participant's life world and to the matrices of this life world: the regimes and institutions that ordain the participant's acceptable, taken-for-granted practices and routines. As with all qualitative research, the boundaries between insider and outsider status are never really fixed. At various times, we have found ourselves engaged as insiders - after a long process of gaining trust - while we were valued in quite another way for our status as outsiders.

For example, when Betty and the researcher discuss public transportation, or when Christine talks about the difficulties involved in doing research, both are inviting the researcher to shift swiftly from an outsider - one who does not share the same chronic illness - to an insider, albeit in another context. Rachel, a pregnant woman, accords the researcher the status of "super-insider" (more insider than Rachel herself) when she uses the researcher as an authoritative source of information about her own future life. Four-year-old Catherine's invitation to "play library" could be understood as an invitation to the researcher to become an insider, but only in the particular context of "play" and only for a brief time. This sometimes recursive nature of the relationship between researcher and participant - from insider to outsider and back — offers the possibility of deep engagement with participants in studies of everyday life information seeking. By being sensitive to how participants regarded us - outsider, insider, or insider-outsider - in relation to the various facets of their life worlds, we allowed them to lead us into discovery. Their regard changed. We constantly asked ourselves: What role do the participants want us to play at a particular moment and for what purpose?

As we noted earlier, reflexivity is a long-standing tenet of the qualitative approach to inquiry. Self-conscious reflection about the research act-long evident in areas such as sociology or anthropology - is a key means by which field workers adapt to new social, cultural, and intellectual conditions (Hammersley \& Atkinson, 1983). With a view to fostering reflexive research practice and open discussion by experienced field researchers in LIS, LIS researchers and practitioners might consider the following factors in their naturalistic studies:

- Respect for participants. Gaining access and trust depend absolutely on feeling and demonstrating respect for participants and their points of view.

- Respect for and sensitivity to the participants' life worlds. Participants do not live in a vacuum. Gaining access often means gaining the trust of their families or colleagues. Maintaining access requires working around the needs and schedules of work and family.

- Flexibility. The research requires creative approaches to gaining access. When an initial idea does not work, investigators are most successful when they manage to "think on their feet" and change strategies as needed.

- Time for developing trust. Gaining trust takes time. Participants first need to consider whether to participate, and then need time to feel comfortable with the research process. When participants recognize the researcher as an insider, initial trust may come quickly. When the researcher is an outsider, participants may need time to assign the researcher a role with which they are comfortable before being ready to disclose.

- Recognition of trust. Although established in different ways with different participants, a trusting relationship needs to be achieved. 
- Maintaining trust. Gaining trust is not a one-time affair, but an ongoing process that begins before the participant makes the initial overture to the researcher, and continues to the present, as investigators recruit additional participants, report their findings, and conduct follow-up studies.

- Role negotiation. The negotiation and revision of shared roles are also part of a continuing process. Although a researcher may begin as an outsider, prolonged engagement affords an opportunity to negotiate new and often unexpected roles.

- Reciprocity. The researcher-participant relationship determines what kinds of reciprocity are most appropriate. As the relationship evolves, reciprocity must be renegotiated.

Although gaining and maintaining access to research participants is not a matter of luck or serendipity, no list of facilitative practices can be produced. As with other aspects of naturalistic research design, access is an emergent process (Lincoln \& Guba, 1985), dependent on the characteristics of the researcher, the participants, and the research context. The participants themselves provide the cues that guide the investigator in the process of negotiating access.

\section{References}

American Psychological Association. (1980). Ethical standards for developmental psychologists: Statement of division of developmental psychology of the American Psychological Association. In D. M. Irwin, \& M. M. Bushnell (Eds.), Observational strategies for child study (pp. 67-68). New York: Holt, Rinehart, \& Winston.

Berg, B. L. (1989). Qualitative research methods for the social sciences. Boston, MA: Allyn \& Bacon.

Busha, C., \& Harter, S. (1980). Research methods in librarianship: Techniques and interpretation. New York: Academic Press.

Carey, R. F. (in progress). Information and narrative: A study of a self-help support group. Unpublished doctoral dissertation, The University of Western Ontario, London, Ontario, Canada.

Chatman, E. A. (1984). Field research: Methodological themes. Library \& Information Science Research, 6, 425-438.

Chatman, E. A. (1996). The impoverished life-world of outsiders. Journal of the American Society for Information Science, 47, 193-206.

Chatman, E. A. (1999). A theory of life in the round: Study of information poverty in a women's maximum security prison. Journal of the American Society for Information Science, 50, $207-217$.

Corsaro, W. (1981). Entering the child's world: Research strategies for field entry and data collection in a preschool setting. In: J. L. Green, \& C. W. Wallat (Eds.), Ethnography and language in educational settings (pp. 117-146). Norwood, NJ: Ablex.

Denzin, N. K., \& Lincoln, \&. (1994). Introduction: Entering the field of qualitative research. In N. K. Denzin, \& Y. S. Lincoln (Eds.), Handbook of qualitative research (pp. 1-18). Thousand Oaks, CA: Sage.

Dunlap, E., \& Johnson, B. D. (1999). Gaining access to hidden populations: Strategies for gaining cooperation of drug sellers/dealers and their families in ethnographic research. Drugs and Society, 14, 127-149.

Erlandson, D. A., Harris, E. L., Skipper, B. L., \& Allen, S. D. (1993). Doing naturalistic inquiry: A guide to methods. Thousand Oaks, CA: Sage.

Ferguson, L. R. (1978). The competence and freedom of children to make choices regarding participation in research: A statement. Journal of Social Issues, 34, 114-121.

Fine, G. A. (1993). Ten lies of ethnography: Moral dilemmas of field research. Journal of Contemporary Ethnography, 23, 267-293. 
Fine, G. A., \& Glassner, B. (1979). Participant observation with children. Urban Life, 8, 153-174.

Fine, G. A., \& Sandstrom, K. L. (1988). Knowing children: Participant observation with minors. Newbury Park, CA: Sage.

Frank, M. A. (1997). The experience of mothers of twins. Unpublished doctoral dissertation, Institute for Clinical Social Work, Chicago.

Glazier, J. D., \& Powell, R. R. (Eds.) (1992). Qualitative research in information management. Englewood, CO: Libraries Unlimited.

Gorman, G. E., \& Clayton, P. (1997). Qualitative research for the information professional: A practical handbook. London, England: Library Association.

Gottlieb, B. H. (1982). Mutual self-help groups: Members' views of their benefits and of roles for professionals. In L. Borman, L. E. Borck, \& R. Hess (Eds.), Helping people to help themselves: Self-help and prevention (pp. 550-567). New York: Hawthorne Press.

Graue, M. E., \& Walsh, D. J. (1998). Studying children in context: Theories, methods, and ethics. Thousand Oaks, CA: Sage.

Green, A.-M., \& Davenport, E. (1999). Putting new media in its place: The Edinburgh experience. In T. D. Wildon \& D. K. Allen (Eds.), Exploring the contexts of information behaviour: Proceedings of the Second International Conference on Research on Information Needs, Seeking, and Use in Different Contexts (pp. 330-342). London: Taylor Graham.

Hammersley, M., \& Atkinson, P. (1983). Ethnography, principles in practice. London, England: Tavistock.

Harrington, B. (1998). "Why do people let us study them?" Social identity and the problem of access in field research. Proceedings of 1998 ASA Annual Meeting (August 21-25 in San Francisco, CA). Washington, DC: American Sociological Association.

Harris, R. M., \& Dewdney, P. (1994). Barriers to information: How formal help systems fail battered women. Westport, CT: Greenwood Press.

Hersberger, J. A. (1998). Everyday information needs and information sources of homeless parents: A study of poverty and perseverance. Unpublished doctoral dissertation, Indiana University, Bloomington.

Julien, H. E. (1999). Barriers to adolescents' information seeking for career decision making. Journal of the American Society for Information Science, 50, 38-48.

Kennedy, M., Humphreys, K., \& Borkman, T. (1994). The naturalistic paradigm as an approach to research with mutual-help groups. In T. J. Powell (Ed.), Understanding the self-help organization: Frameworks and findings (pp. 172-189). Thousand Oaks, CA: Sage.

Kingree, J. B., \& Ruback, B. (1994). Understanding self-help groups. In T. J. Powell (Ed.), Understanding the self-help organization: Frameworks and findings (pp. 272-292). Thousand Oaks, CA: Sage.

Lincoln, Y. S., \& Guba, E. G. (1985). Naturalistic inquiry. Newbury Park, CA: Sage.

Lofland, J. B., \& Lofland, L. H. (1984). Analyzing social settings: A guide to qualitative observation and analysis. Belmont, CA: Wadsworth.

Losee, R. M., \& Worley, K. A. (1993). Research and evaluation for information professionals. San Diego, CA: Academic Press.

Mandell, N. (1988). The least-adult role in studying children. Journal of Contemporary Ethnography, 16, $433-467$.

McKechnie, L. E. F. (1996). Opening the "Preschoolers' Door to Learning": An ethnographic study of the use of public libraries by preschool girls. Unpublished doctoral dissertation. The University of Western Ontario, London, Ontario.

McKechnie, L. E. F. (2000). Ethnographic observation of preschool children. Library and Information Science Research, 22, 61-76.

McKenzie, P.J. (2001). Negotiating authoritative knowledge: Information practices across a life transition. Unpublished doctoral dissertation. The University of Western Ontario, London, Ontario.

Mellon, C. A. (1990). Naturalistic inquiry for library science: Methods and applications for research, evaluation, and teaching. New York: Greenwood Press.

Mills, C. W. (1959). The sociological imagination. New York: Oxford University Press. 
Oakley, A. (1981). Interviewing women: A contradiction in terms. In H. Roberts (Ed.), Doing feminist research (pp. 30-61). London, England: Routlege \& Kegan Paul.

Ostrander, S. A. (1993). "Surely you're not in this just to be helpful": Access, rapport and interviews in three studies of elites. Journal of Contemporary Ethnography, 22, 7-27.

Palys, T. (1997). Research decisions: Quantitative and qualitative perspectives (2nd ed.). Toronto, ON: Harcourt Brace.

Pernoll, M. L., \& Benson, R. C. (1994). Multiple pregnancy. In A. H. DeCherney, \& M. L. Pernoll (Eds.), Current obstetric and gynecologic diagnosis and treatment (8th ed., pp. 357-367). Norwalk, CT: Appleton \& Lange.

Pettigrew, K. E. (1999). Waiting for chiropody: Contextual results from an ethnographic study of information behaviour among attendees at community clinics. Information Processing \& Management, 35, 801-817.

Powell, R. R. (1997). Basic research methods for librarians (3rd ed.). Greenwich, CT: Ablex.

Rappaport, J. (1994) Narrative studies, personal stories, and identity transformation in the mutual help context. In T. Powell (Ed.), Understanding the self-help organization: Frameworks and findings (pp. 115-135). Thousand Oaks, CA: Sage Publications.

Reay, D. (1995). The fallacy of easy access. Women's Studies International Forum, 18, 205-213.

Savolainen, R. (1995). Everyday life information seeking: Approaching information seeking in the context of "way of life". Library and Information Science Research, 17, 259-294.

Stanley, B., Sieber, J. E. (Eds.) (1992). Social research on children and adolescents: Ethical issues. Newbury Park, CA: Sage.

Talja, S. (1997). Constituting 'information' and 'user' as research objects: A theory of knowledge formations as an alternative to the information-man theory. In P. Vakkari, R. Savolainen, B. Dervin (Eds.), Information seeking in context: Proceedings of an international conference on research in information needs, seeking and use in different contexts, 14-16 August, 1996, Tampere, Finland (pp. 67-80). London, England: Taylor Graham.

Thompson, R. A. (1992). Developmental changes in research risk and benefit: A changing calculus of concern. In B. Stanley, \& J. E. Sieber (Eds.), Social research on children and adolescents: Ethical issues (pp. 31-64). Newbury Park, CA: Sage.

Vakkari, P. (1997). Information seeking in context: A challenging metatheory. In P. Vakkari, R. Savolainen, \& B. Dervin (Eds.), Information seeking in context: Proceedings of an international conference on research in information needs, seeking and use in different contexts, 14-16 August, 1996, Tampere, Finland (pp. 451-464). London: Taylor Graham.

Van der Zalm, J. E. (1995). Accommodating twin pregnancy: Maternal process. Acta Geneticae Medicae et Gemellogiae, 44, 117-133.

Whyte, W. F. (1943). Street corner society: The social structure of an Italian slum. Chicago, IL: University of Chicago Press.

Williamson, K. (1997). The information needs and information-seeking behaviour of older adults: An Australian study. In P. Vakkari, R. Savolainen, B. Dervin (Eds.), Information seeking in context: Proceedings of an international conference on research in information needs, seeking and use in different contexts, 14-16 August, 1996, Tampere, Finland (pp. 337-350). London, England: Taylor Graham. 